\title{
Pain levels of examined muscles and gender differences in pain during electromyography
}

\author{
Elektromiyografi sirasinda incelenen kaslarin \\ ağr diuzeyleri ve ăgrıda cinsiyet farkları
}

Pınar YALINAY DIKMEN, Elif ILGAZ AYDINLAR, Geysu KARLIKAYA

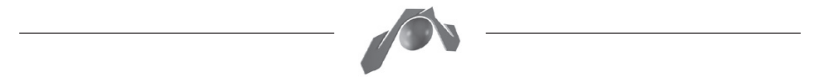

\begin{abstract}
Summary
Objectives: The aim of this study was to evaluate the pain level of each muscle during an EMG study and also search for any association between the pain levels and gender.

Methods: Two hundred and twenty-seven subjects (166 females and 111 males) participated in the present study. Numeric analogue scale (NAS) was obtained from the patients after needle EMG for each muscle.

Results: In total, 1242 muscles were examined. The highest pain levels among examined muscles were found on Abductor Pollicis Brevis (APB) (5.8 \pm 2.6$)$, First Dorsal Interosseous (4.2 \pm 2.6$)$ and Vastus Lateralis (4.0 \pm 2.6$)$. NAS levels of the female patients $(4.3 \pm 2.7)$ were apparently higher than those of the male patients $(2.8 \pm 2.3)(\mathrm{p}<0.01)$.

Conclusion: First Dorsal Interosseous muscle was found less painful than APB muscle for the patients. Our study displayed greater pain sensitivity among females compared with males during the needle EMG; however, the pain levels of examined muscles were not higher than moderate for both genders.
\end{abstract}

Key words: Electromyography; EMG; muscle; needle EMG; pain perception.

Özet

Amaçः Bu çalı̧̧manın amacı EMG incelemesi sırasında kaslardaki ağrı düzeylerinini değerlendirmek ve ayrıca cinsiyet ile ağrı düzeyleri arasındaki ilişkiyi araştırmaktır.

Gereç ve Yöntem: İki yüz yirmi yedi olgu (166 kadın, 111 erkek) çalışmaya katıldı. Numerik analog skala (NAS)'sı ber kas için iğne EMG'si sonrasinda öğrenildi.

Bulgular: Toplamda 1242 kas incelendi. Incelenen kaslar arasinda en yüksek NAS düzeyleri Abduktor Pollisis Brevis (APB)

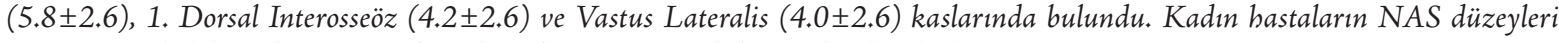
(4.3 \pm 2.7$)$ erkek hastalarin NAS düzeylerinden $(2.8 \pm 2.3)$ belirgin olarak yüksekti $(p<0.01)$.

Sonuç: Hastalar için 1. Dorsal Interosseöz kası APB kasından daha az ağrılı bulundu. Çalı̧mamız kadınların iğne EMG'de erkekelere kıyasla daba yüksek ağrı düzeyleri bildirdiğini, ancak her iki cinsde de incelenen kaslarda ağr düzeylerinin ortadan daba yüksek olmadığını ortaya koymuştur.

Anahtar sözcükler: Elektromiyografi; EMG; kas; iğne EMG; ağrı algısı.

\section{Introduction}

Electromyography (EMG) is a painful examination which is widely used to evaluate peripheral nervous system lesions. An association has been noted between EMG-induced pain and female gender, ${ }^{[1-5]}$ pre-test pain level, ${ }^{[3]}$ EMG-related anxiety, ${ }^{[3,6]}$ inef- fective coping strategies, ${ }^{[3]}$ specific muscles ${ }^{[2]}$ and the type of recording electrodes for needle EMG, ${ }^{[5,7-9]}$ while no relationship has been established between pain and race, level of education, number of examined muscles, or characteristics of the examiner. ${ }^{[2,3]}$

Department of Neurology, Acıbadem University School of Medicine, Istanbul, Turkey Acıbadem Üniversitesi Tıp Fakültesi, Nöroloji Anabilim Dalı, İstanbul

Submitted (Başvuru tarihi) 22.10.2013 Accepted after revision (Düzeltme sonrası kabul tarihi) 01.09.2014

Correspondence (İletişim): Dr. Pınar Yalınay Dikmen. Acıbadem Maslak Hastanesi, Büyükdere Caddesi, No: 40, Maslak, 34457 Sarıyer, İstanbul, Turkey.

Tel: +90 - 212 - 3044455 e-mail (e-posta): pinarya@hotmail.com 
We observed that the pain tolerance of patients differs from patient to patient and from muscle to muscle in the same patient. Our aim was to evaluate the pain level of each muscle during EMG and search for any association between the pain levels and gender.

\section{Materials and Methods}

The present study was approved by the Acrbadem University Medical Committee on Clinical Investigation. Written informed consent was obtained from all subjects prior to enrolment in the study. The subjects were adult patients who received a diagnosis of entrapment neuropathy or radiculopathy between June 2011 and February 2012 and were subsequently referred to the EMG laboratory at Acrbadem University. Exclusion criteria included individuals who were seriously ill, displayed impaired consciousness, were illiterate, with previous history of EMG, were diagnosed with polyneuropathy or were currently taking medications that affect pain, such as non-steroidal anti-inflammatory or antidepressant medications. The age, height, and weight of participants were recorded.

Verbal and written information about the EMG procedure was provided to all subjects. Numeric analogue scales (NAS) ranging from $0 \mathrm{~cm}$ (i.e., no pain) to $10 \mathrm{~cm}$ (i.e., worst pain imaginable) was used to measure pain. NAS measurements were obtained from the patients before electrophysiological examination (baseline pain) and after needle EMG for each muscle. The needle EMG was done by three examiners depending on referral diagnosis. The muscles were carried out from proximal to distal by needle EMG on an upper extremity, while the muscles were exa- mined from distal to proximal on a lower extremity. The type of disposable concentric needle electrodes and needle movement techniques were consistent across examiners (i.e., $0.46 \mathrm{~mm}$ in diameter and 37 $\mathrm{mm}$ in length; Medelec, Oxford Instruments, Surrey, UK, catalogue number: X53156). The required needle movements were $0.5-1 \mathrm{~cm}$, which resulted in an EMG burst of 300-500 ms in normal muscle. A needle electrode was inserted into four different regions of muscle through one skin insertion site. Three successive depths were sampled for each along each side of a pyramid. ${ }^{[10]}$ Examiners rehearsed in order to standardize their technique before the study began. The total number of muscles tested with needle EMG was recorded. Facial and trunk muscles were not evaluated. The EMG procedure took approximately 20-30 minutes for each patient. At least three muscles were examined in each patient.

Means and standard deviations were calculated for each variable. ANOVA was used for comparison of muscles' NAS levels and to determine variation among the investigators. Extansor digitorum brevis (EDB) muscle NAS levels were not included statistical analysis because of insufficient number of patients. The level of significance was set at $\mathrm{p}<0.05$.

\section{Results}

Two hundred and seventy-seven subjects (166 females and 111 males) participated in the present study. The subjects were 18-75-years-old, with a mean age of $40.6 \pm 12.8$. Patients' height, and weight were $169.4 \pm 9.3 \mathrm{~cm}$ (range: $150-210 \mathrm{~cm}$ ), $72.9 \pm 15.0 \mathrm{~kg}$ (range: $45-125 \mathrm{~kg}$ ), respectively. The subjects' referral diagnoses included entrapment neuropathy

Table 1. Pain levels of examined muscles

\begin{tabular}{lccc}
\hline Upper extremity muscles & NAS \pm SD & Lower extremity muscles & NAS \pm SD \\
\hline Deltoid $(n=168)$ & $2.7 \pm 2.4$ & Tibialis anterior $(n=97)$ & $3.2 \pm 2.5$ \\
Biceps $(n=185)$ & $3.5 \pm 2.6$ & Gastrocnemius-med $(n=97)$ & $3.8 \pm 2.7$ \\
Triceps $(n=177)$ & $3.9 \pm 2.6$ & Vastus lateralis $(n=88)$ & $4.0 \pm 2.6$ \\
Brachioradialis $(n=96)$ & $3.5 \pm 2.6$ & Vastus medialis $(n=76)$ & $3.8 \pm 3.0$ \\
Extensor digitorum communis $(n=85)$ & $3.7 \pm 2.6$ & Rectus femoris $(n=73)$ & $3.2 \pm 2.7$ \\
Flexor carpi radialis $(n=86)$ & $3.6 \pm 2.6$ & Iliopsoas $(n=60)$ & $2.9 \pm 2.4$ \\
First dorsal interosseous $(n=177)$ & $4.2 \pm 2.6$ & Tensor fasia lata $(n=52)$ & $2.3 \pm 2.4$ \\
Abductor pollicis brevis $(n=110)$ & $5.8 \pm 2.6$ & Extensor digitorum brevis* $(n=12)$ & $5.1 \pm 2.4$ \\
\hline
\end{tabular}

NAS: Numeric Analogue Scale; SD: Standard deviation; *NAS levels of EDB were not included statistical analysis due to insufficient number of patients. 
$(\mathrm{N}=117)$ and radiculopathy $(\mathrm{N}=110)$. Eighty patients had lower extremity procedures, 177 patients had upper extremity procedures, and 20 patients had both. The results of the EMG studies were normal in 132 patients, while 145 patients had abnormal EMG results.

Baseline pain levels of patients were $1.2 \pm 2.4$. Three investigators were examined 1242 muscles (muscles number of female $\mathrm{n}=687$, and male $\mathrm{n}=555$ ). NAS levels of the muscles are demonstrated in Table 1.

Abductor pollicis brevis (APB) muscle had the highest pain level (5.8 \pm 2.6$)$ amongst all upper and lower extremity muscles. Abductor pollicis brevis muscle had a significant higher NAS level compared to deltoid muscle muscle $(\mathrm{p}<0.01, \mathrm{df}=50)$. NAS level of first dorsal interosseous (FDI) muscle was also higher than deltoid $(\mathrm{p}<0.01, \mathrm{df}=167)$ like $\mathrm{APB}$. The pain levels of two distal muscles (APB vs. FDI) showed statistical difference $(\mathrm{p}<0.01, \mathrm{df}=801)$. NAS levels of EDB muscle were the highest of lower extremity muscles; however, EDB muscle was not included statistical analysis because of insufficient number. There was no difference among the NAS levels of vastus lateralis, vastus medialis and rectus femoris muscles, which were femoral nerve innervated muscles.

The NAS levels of female patients $(4.3 \pm 2.7)$ were apparently higher than the male patients $(2.8 \pm 2.3)$ $(\mathrm{p}=0.00)$. NAS levels of muscles obtained from patients by three different examiners were not showed statistically difference $(\mathrm{p}=0.33)$.

\section{Discussion}

Although the pain during EMG is generally tolerable, electromyographers usually observe that the amount of experienced pain depends on the examined muscles. In this study, pain levels of both upper and lower extremities' muscles were lower than moderate, so these findings are associated with our observations in daily practice.

In this study, the most painful muscles were $\mathrm{APB}$ and EDB, which often are not selected by examiners, because they are painful and some denervation may be seen in normal subjects without symptoms. ${ }^{[1]}$ They are both distal muscles, although EDB muscle were not included statistical analysis due to insufficient number of patients, it seems that distal muscles are more painful than proximal ones (deltoid vs. APB and FDI). This study showed significant statistical differences between APB and FDI muscles' pain levels. NAS levels of APB muscle were higher than FDI muscle and also moderate level. This finding could be important in muscle selection while doing EMG for upper extremity radiculopathies. The reason that the hand and foot muscles are more painful than proximal ones might be that they are too small and the probability for needle electrode coming close to any motor end-plate zone could be increased. Another explanation of different pain levels of the body parts could be the peripheral nociceptor density of hands and feet. Depending on the type of nociceptor activated, pain- related information conveys to spinal cord and makes synaptic connections within eight distinct laminae of dorsal horn. It has been known that pain was not processed in a single cortical area, but in several distributed brain regions. ${ }^{[12,13]}$ Neuroimaging studies showed that the cortical and subcortical brain areas activated by nociceptive stimulation includes: anterior cingulate cortex, insula, frontal cortices, primary somatosensory cortex and second somatosensory cortex ${ }^{[14]}$ and are often referred as the pain matrix. ${ }^{[15]}$ It is well-known that foot and hands have a larger representation space in the motor and somatosensory homunculus. That might be the possible cause that hand and foot areas which have larger representation in pain matrix than others and since they are more painful compared to other muscles.

Studies have shown that women use more health care services than mens, ${ }^{[16-18]}$ moreover a number of studies have demonstrated a higher prevalence of chronic pain states and greater pain sensitivity among women compared with men. ${ }^{[2,3,19,20]}$ In our data is consistent with previous studies ${ }^{[2,3]}$ and indicated greater pain levels among females compared with males.

In conclusion, the pain perceived by the patients during EMG of extremity muscles was not higher than moderate except for APB. Comparison of two distal muscles of upper extremity regarding pair showed that selecting FDI was less painful for the patient. As expected females' pain levels were greater 
than males. These findings might give practical and beneficial insight to the physician, who informs the patient about EMG.

\section{Conflict-of-interest issues regarding the author- ship or article: None declared.}

\section{Peer-rewiew: Externally peer-reviewed.}

\section{References}

1. Kothari MJ, Preston DC, Plotkin GM, Venkatesh S, Shefner JM, Logigian EL. Electromyography: do the diagnostic ends justify the means? Arch Phys Med Rehabil 1995;76(10):947-9.

2. Gans BM, Kraft GH. Pain perception in clinical electromyography. Arch Phys Med Rehabil 1977;58(1):13-6.

3. Khoshbin S, Hallett M, Lunbeck R. Predictors of patients' experience of pain in EMG. Muscle Nerve 1987;10(7):629-32.

4. Meadows JC. Observations on muscle pain in man, with particular reference to pain during needle electromyography. J Neurol Neurosurg Psychiatry 1970;33(4):519-23. CrossRef

5. Walker WC, Keyser-Marcus LA, Johns JS, Seel RT. Relation of electromyography-induced pain to type of recording electrodes. Muscle Nerve 2001;24(3):417-20. CrossRef

6. Jan MM, Schwartz M, Benstead TJ. EMG related anxiety and pain: a prospective study. Can J Neurol Sci 1999;26(4):294-7.

7. Strommen JA, Daube JR. Determinants of pain in needle electromyography. Clin Neurophysiol 2001;112(8):1414-8.

8. Pease WS, Bowyer BL. Motor unit analysis. Comparison between concentric and monopolar electrodes. Am J Phys Med Rehabil 1988;67(1):2-6. CrossRef
9. Sherman HB, Walker FO, Donofrio PD. Sensitivity for detecting fibrillation potentials: a comparison between concentric and monopolar needle electrodes. Muscle Nerve 1990;13(11):1023-6. CrossRef

10. Cohen HL, Brumlik J. A Manual of Electroneuromyography. New York: Harper\&Row Publishers; 1968. p.40.

11. Preston DC, Shapiro BE, (eds). Electromyography and neuromuscular disorders. 2nd ed. Philadelphia, Pennsylvania: Butterworth Heinemann; 2005. p.184.

12. Talbot JD, Marrett S, Evans AC, Meyer E, Bushnell MC, Duncan $\mathrm{GH}$. Multiple representations of pain in human cerebral cortex. Science 1991;251(4999):1355-8. CrossRef

13. Jones AK, Friston K, Frackowiak RS. Localization of responses to pain in human cerebral cortex. Science 1992;255(5041):215-6. CrossRef

14. Peyron R, Laurent B, García-Larrea L. Functional imaging of brain responses to pain. A review and meta-analysis (2000). Neurophysiol Clin 2000;30(5):263-88. CrossRef

15. Ingvar M. Pain and functional imaging. Philos Trans R Soc Lond B Biol Sci 1999;354(1387):1347-58. CrossRef

16. Cleary PD, Mechanic D, Greenley JR. Sex differences in medical care utilization: an empirical investigation. J Health Soc Behav 1982;23(2):106-19. CrossRef

17. Hibbard JH, Pope CR. Gender roles, illness orientation and use of medical services. Soc Sci Med 1983;17(3):129-37. CrossRef

18. Waldron I. Sex differences in illness incidence, prognosis and mortality: issues and evidence. Soc Sci Med 1983;17(16):1107-23. CrossRef

19. Quiton RL, Greenspan JD. Sex differences in endogenous pain modulation by distracting and painful conditioning stimulation. Pain 2007;132 Suppl 1:S134-49. CrossRef

20. Wiesenfeld-Hallin Z. Sex differences in pain perception. Gend Med 2005;2(3):137-45. CrossRef 